\title{
Premonitory Ailments indicative of Incipient Pulmonary Tuberculosis [Propathies révelatrices de tuberculose pulmonaire]. (Le Progres Medical, May 5th, 1917.) Raymond, Dr. Paul.
}

Although not of direct psychiatrical interest, having regard to the fact that phthisis is of such common occurrence in asylums, and also to the importance of early diagnosis upon which a favourable result so often depends, this paper is of considerable interest from a clinical point of view, and not without practical value.

That such affections as sciatica (neuralgic variety), herpes zoster, psoriasis, erythema nodosum, and possibly arthritic disorders, are not infrequently prodromata of tuberculosis is probably not very generally known. That the detection of pulmonary phthisis in its earliest stages is often extremely difficult is admitted by most author ties ; any means, therefore, which will aid in its discovery hefore the disease becomes established becomes of unquestionable value. And Dr. Raymond urges the importance of a most careful examination of the lungs in any case in which the above-mentioned diseases occur. At the Larrey military hospital at Versailles he has had opportunities of observing many cases which exemplified the connection between these maladies and tuberculosis. None of the patients were sent into hospital on account of pulmonary trouble, but with a view to treatment of the more obvious affections from which they were suffering. Thus, five cases of sciatica were admitted, one of whom was also the subject of psoriasis and arthritic troubles, and the point of importance about these cases is that the minor affections in most instances manifest themselves long (in one case twenty-one months) before any pulmonary mischief reveals itself. And patients sometimes appear to be in robust health when first seen, and then, only some months later, begin to suffer from any overt signs of commencing phthisis, such as cough, loss of weight, etc. In many of them there was a tubercular family history. Dr. Raymond attributes the prodromal maladies to the action of bacillary toxins on peripheral nerves, and, through them, on the skin, starting from a latent pulmonary tubercular focus.

Dr. Raymond does not claim to be the first to note the connection between phthisis and these prior ailments which he has found to be so often the prelude to it. Peter, in the case of sciatica; Leudet, Lemonnier, and Flers, in that of zona ; Gauchet, as regards psoriasis ; and several writers with respect to erythema nodosum have drawn attention to the relationship between these and pulmonary disease. But he considers the profession generally does not realise the importance of such connection, and its usefulness as affording an opportunity for much earlier treatment of tuberculous patients than would otherwise be the case. The practical outcome of his researches is to emphasise the necessity in every such case, especially if persistent and obstinate to treatment, of making a minute and exhaustive examination of the hungs for signs of incipient disease, and not to be too ready to regard. them as distinct autonomous morbid entities.

The facts already known as regards the development of psoriasis over the area of a nerve distribution enable us to understand how this may be similar to what occurs in zona, in so far as both may be evi-

LXIII. 
dence of a suffering nerve reacting to a bacillary toxin. The relation of erythema nodosum to innervation is more difficult to comprehend, but the fact of its localisation always in the same areas is a proof of the intervention of the nervous system. By its susceptibility to microbic poisons, and particularly to those of tuberculosis, the nervous system becomes a veritable touchstone, and plays a highly important róle in diagnostic procedure. T. DRAPES.

\section{Part IV.- Notes and Nows. \\ THE MEDICO-PSYCHOLOGICAL ASSOCIATION OF GREAT BRITAIN AND IRELAND.}

The Seventy-Sixth Annual Meeting of the Association was held in the rooms of the Medical Society of London, on Wednesday, July 25th, 1917, Lieut.-Colonel David G. Thomson, M.D., R.A.M.C., President, in the chair.

There were present: Sir George H. Savage, Drs. T. Stewart Adair, G. F. Barham, A. Helen Boyle, D. Bower, P. E. Campbell, M. Craig, J. Chambers, W. H. Coupland, J. F. Dixon, E. L. Dove, T. Drapes, J. H. Earls, R. Eager, F. H. Edwards, C. F. Fothergill, A. H. Griffith, H. E. Haynes, G. B. James, G. H. Johnston, J. C. Johnstone, J. Keay, N. T. Kerr, N. Lavers, H. WolseleyLewis, C. Mercier, A. Miller, G. E. Miles, H. H. Newington, H. J. Norman, E. S. Pasmore, H. Rayner, J. N. Sergeant, G. E. Shuttleworth, R. Percy Smith, J. G. Soutar, J. B. Spence, T. E. K. Stansfield, James Stewart, R. C. Stewart, H. F. Stilwell, R. J. Stilwell, J. Tattersall, J. Turner, E. W. White, and R. H. Steen (Acting Hon. General Secretary).

Visitor: Dr. J. F. Briscoe.

Present at the Council Meeting: Lieut.-Colonel D. G. Thomson, M.D., R.A.M.C. (President), in the chair, and Drs. T. S. Adair, J. Chambers, T. Drapes, R. Eager, J. Keay, N. Lavers, A. Miller, H. H. Newington, H. J. Norman, J. N. Sergeant, J. G. Soutar, T. E. K. Stansfield, H. Wolseley-Lewis, and R. H. Steen (Acting Hon. General Secretary).

The following sent communications expressing regret at their inability to be present: Drs. J. R. Gilmour, G. D. McRae, R. R. Leeper, C. C. Easterbrook, W. H. B. Stoddart, John Mills, R. B. Campbell, G. N. Bartlett, J. G. Porter Phillips, R. L. Oswald, and R. H. Cole.

\section{Minutes.}

The President said that as the minutes of the last annual meeting had already appeared in the Journal, perhaps it would be the wish of the meeting to take them as read.

This was agreed to, and the minutes were signed.

Election of Orficers, Council, and Standing Committers.

The President nominated Drs. Turner, Adair, Dixon, and Norman as scrutineers for the ballot.

After the ballot had been taken

The PREsIDENT declared that the officers who had been nominated had been duly elected.

Election of Auditors.

The President said Dr. Percy Smith and Dr. Maurice Craig had acted in that capacity for the past year, but Dr. Percy Smith wished to be-relieved of his duties, so that it became necessary to elect another auditor to take his place. He understood that Dr. Edwards, of Camberwell House, was willing for his name to be put forward to fill the post. Drs. Maurice Craig and Edwards were accordingly elected. 